\title{
Giving Voice to Narratives of Institutional Sex Abuse
}

\section{ABSTRACT}

The announcement of Australia's Royal Commission into Institutional Child Sexual Abuse was the culmination of a long campaign by survivor groups to have their stories heard. Although this campaign, and the organisations themselves date only from the last years of the twentieth century, institutional sexual abuse has a far longer history. This paper will seek to trace the evidence of sexual abuse back into the nineteenth century and ask why it took so long for survivors to have their stories heard. It will argue that while institutional responses to allegations of sexual abuse remained remarkably consistent over time, it was only in the aftermath of the feminist (re)discovery of child sexual abuse in the 1970s that survivors were able to access a language through which to understand and articulate their experiences.

Without access to such a language enabling them to position themselves as victims of rather than complicit in such abusive behaviours survivors were ill-equipped to resist the attempts by those in authority to silence their concerns. 


\section{Giving Voice to Narratives of Institutional Sex Abuse}

\section{Shurlee Swain ${ }^{1}$}

'All children deserve a safe and happy childhood', the charge to Australia's Royal Commission into Institutional Child Sexual Abuse begins. It continues by recognising the nation's international responsibilities to protect children from all forms of abuse, before narrowing in on child sexual abuse as its exclusive focus.. ${ }^{2}$ In so doing it follows a path which has become familiar both nationally and internationally. The (re)discovery of child abuse in the 1960s was, by the 1980s, overwhelmed by a focus on child sexual abuse, characterised as the most extreme transgression of the supposed innocence of childhood. ${ }^{3}$ The emphasis on institutional child sexual abuse has brought into the spotlight religious organisations which played such a major role in the provision of out-of-home care for children and the degree to which this exposed them to the risk of clerical abuse. This paper aims to track this transition, explaining how the relationship between government and the

\footnotetext{
${ }^{1}$ Shurlee Swain is Professor of Humanities at Australian Catholic University whose work has informed several of the recent Australian inquiries into institutional abuse. Postal address: Locked Bag 4115 Fitzroy MDC, Vic 3065. Email: shurlee.swain@acu.edu.au

${ }^{2}$ Royal Commission into Institutional Responses to Child Sexual Abuse 'Terms of reference' 2013 Royal Commission into Institutional Responses to Child Sexual Abuse website http://www.childabuseroyalcommission.gov.au/about-us/terms-of-reference accessed April
} 28,2014

${ }^{3}$ Scott Dorothy and Swain Shurlee Confronting Cruelty: Historical Perspectives on Child Abuse Melbourne Melbourne University Press 2002 pp 150-73 
churches functioned to both foster abuse and suppress its disclosure and exploring the ways in which the feminist analysis of child sexual abuse, articulated particularly in the work of Linda Gordon in the 1970s helped to give victim/survivors the language through which to bring their experiences into the public domain.

Although the feminist concern was with the abuse of girls within the family home, the new discourse, adopted by predominantly male survivor/victims of extra-familial clerical abuse, built upon notions of childhood innocence which stood in sharp contradistinction to the libertarian analyses of child sexuality that had developed within both the women's and the gay liberation movements. Using the testimony presented to recent Australian inquiries, this paper seeks to trace the way in which this new discourse has been used by care leavers to name their experiences as abusive and to identify the failures in the systems charged with their care that allowed such abuse to occur. While such testimony does not give access to a factual account of institutional life it does demonstrate the way in which the abuse was experienced and understood and how these understandings have changed over time. Through the analysis of this testimony the article is able to show how pre-existing conceptions of the children as morally tainted, combined with a culture of denial amongst care givers, and the authorities responsible for their regulation and supervision, to create an environment in which abuse was able to thrive.

\section{Inquiries into past welfare practices}

The beginning of Australia's series of public inquiries into past child welfare practices is usually dated to the National Inquiry into the Separation of Aboriginal and Torres Strait Islander Children from their Families which arose in response to evidence from the Royal Commission on Deaths in Custody of the impact of child removal on Australian Indigenous communities. The terms of reference made no mention of sexual abuse but in the evidence 
presented there were more than 502 instances noted, earning the phenomenon its own section within the final report released in $1997 .{ }^{4}$ The two subsequent Federal inquiries, Lost Innocents and Forgotten Australians, followed a similar trajectory, with sexual abuse absent from the terms of reference but identified in the subsequent reports as prevalent in the institutions which housed child migrants and local children taken into care. ${ }^{5}$ In the report of the inquiry into abuse in Queensland institutions completed in 1999, sexual abuse was considered as one of four forms of abuse that were found to be endemic in the system. ${ }^{6}$ However, when South Australia instigated its own inquiry early in the new century the focus had narrowed, with sexual abuse positioned alongside deaths in care as the core subjects for investigation as indeed it became for the Victorian inquiry which reported in late $2013 .^{7}$

\footnotetext{
${ }^{4}$ Human Rights and Equal Opportunity Commission (HREOC) Bringing Them Home: Report of the National Inquiry into the Separation of Aboriginal and Torres Strait Islander
} Children from their Families Sydney HREOC. 1997 pp 162-7

${ }^{5}$ Australian Senate Community Affairs References Committee Lost Innocents: Righting the Record Report on Child Migration Canberra Senate Printing Unit 2001 pp 75-80; Australian Senate Community Affairs References Committee Forgotten Australians: A Report on Australians who Experienced Institutional or Out-of-home Care as Children Canberra: Senate Printing Unit 2004 pp 103-5

${ }^{6}$ Forde Leneen Report of the Commission of Inquiry into Abuse of Children in Queensland Institutions Brisbane The Inquiry 1999 pp iv 87-91

${ }^{7}$ Mullighan Edward Children in State Care: Commission of Inquiry: Allegations of Sexual Abuse and Death from Criminal Conduct Adelaide: South Australian Government 2008; Parliament of Victoria Family and Community Development Committee Betrayal of Trust: Inquiry into the Handling of Child Abuse by Religious and Other Non-government Organisations Melbourne: Family and Community Development Committee 2013. 
Internationally a similar pattern prevails. Anne-Marie McAlinden identified three distinct periods in her chronology of inquiries into child welfare in Ireland. From the 1930s to the 1970s the focus was on the lack of basic care within institutional environments, from the 1970 s to the 1990s attention turned to abuse within the family and the failure of child protection services, but from the late 1990s the paedophile priest claimed centre stage. ${ }^{8}$ The Shaw inquiry, which reported in 2008, dated the rise of concern about sexual abuse in relation to out-of-home care in Scotland to the 1980s, but noted that the issue itself was not new, documenting inquiries in other parts of the British Isles dating back to the 1940s. The distinction was, however, that these inquiries were conducted internally, and culminated with the offender being removed, but prosecution avoided in order to preserve the reputation of the organisation involved. 'Although sexual abuse was not a public concern at this time', the report concluded, 'it was still recognised that staff could be sexually attracted to children'. ${ }^{9}$ The inclusion of a clause making it an offence for any member of staff to 'commit an act of sexual immorality' with children in their care in the 1913 Scottish Mental Deficiency and Lunacy Act, would suggest that this awareness was almost as old as the institutions themselves. ${ }^{10}$

The thin documentary evidence in the public domain in Australia points to a similar scenario. In 1875 Victorian newspapers reported the dismissal of the Geelong Orphan

\footnotetext{
${ }^{8}$ McAlinden Anne-Marie 'An Inconvenient Truth: Barriers to Truth Recovery in the Aftermath of Institutional Child Abuse in Ireland' (2012) 33 Legal Studies p. 5-6 at 1.

${ }^{9}$ Shaw Tom Historical Abuse Systemic Review: Residential Schools and Children's Homes in Scotland 1950 to 1995 Edinburgh Scottish Government 2007 p 28

${ }^{10}$ As above at 60
} 
Asylum ${ }^{11}$ superintendent after the girl charged with 'tending his private apartments' was found to be pregnant. Another staff member who had known of the pregnancy for three months without informing the committee was also dismissed, but nothing was noted as to the fate of the young woman. ${ }^{12}$ In 1899 the superintendent of the Strathfield Institution for the Blind defended himself against charges of improper behaviour from several of the female residents. The offences had taken place five years previously and the superintendent's wife accused the now adult complainants of having ulterior motives in bringing the matter to public attention, saying: 'As you kept it to yourself so long you might have kept it altogether. You only tell me in order to break my heart'. ${ }^{13}$ In 1900 Australian papers aired stories of the return to New Zealand of a Marist brother charged with five counts of indecent assault involving residents of a boys reformatory in Stoke. The charges failed after 'the principal witness ... contradicted himself, and finally admitted having been guilty himself of similar offences upon his school-fellows ... The judge ... remarked that he could not punish a cat upon such testimony' but the reformatory was removed from the Brothers' control. ${ }^{14}$

The evidence presented to recent inquiries suggests that these were far from isolated instances. In Queensland, Leneen Forde concluded, 'complaints of sexual abuse ... emerged in almost all of the institutions under consideration. ${ }^{15}$ South Australia's Mullighan report agreed.

The alleged sexual abuse occurred in every type of care from the 1940s onwards, including institutional care (large congregate care in government and non-government

${ }^{11}$ Details of all the institutions mentioned in this article are available at http://www.findandconnect.gov.au/

12 'General Items' The North Melbourne Advertiser 22 January 1875 p 2

13 'Sydney Libel Action Western Mail (Perth) 25 August 1899 p 28

14 'Stoke Orphanage Scandals' Kalgoorlie Western Argus 4 December 1900 p 37. "

${ }^{15}$ Forde above note 6 at 87 
homes up to the 1970s), smaller group care (cottages, hostels and youth shelters from the 1960s to early 1980s), residential care units (admission, assessment and community units from the 1970s to the present), foster care (placements with other families from the 1940 s to the present), family care (placement on probation to live at the family home from the 1940s to the present) and in secure care facilities (from the 1950s to the present). ${ }^{16}$

Nor was this abuse unknown to the authorities, with a series of investigations conducted from the 1940s on, all of which were resolved internally, usually by the relocation of the children involved. ${ }^{17}$

\section{Feminists and the (re)discovery of child sexual abuse}

The explanation for the silence around such instances of sexual abuse, American scholar, Linda Gordon has argued, was the absence of a feminist voice, or a feminist consciousness to provide the language through which concerns could be articulated. Without such a feminist voice, she suggests, the identification of instances of child sexual abuse served only to supply 'evidence and arguments for constricting and disempowering children'. ${ }^{18}$ When complaints were investigated the focus was on the sexual knowingness of the child rather than the offender who was more likely to be seen as pathetic than predatory. ${ }^{19}$ Gordon's article appeared as part of a feminist response to the 1987 Cleveland scandal in Britain, in which

\footnotetext{
${ }^{16}$ Mullighan above note 7 at xiii

17 As above at 33 .

${ }^{18}$ Gordon Linda 'The Politics of Child Sexual Abuse: Notes from American History' (1988) 28 Feminist Review: Special Issue Family Secrets: Child Sexual Abuse, p 61 at 56.

${ }^{19}$ Angelides Steven 2005. 'The Emergence of the Paedophile in the Late Twentieth Century' (2005) 36 Australian Historical Studies p 278 at 272.
} 
parents were found to have been falsely accused of abusing their children. The consequent inquiry, which provided support for calls to reduce the role of the State in relation to intrafamilial child sexual abuse, threatened to reverse the gains that feminists believed they had made. Gordon's contribution, as a historian, was to show how, in the early decades of the twentieth century, 'powerful ideological tanks' had been able to render victims 'invisible and mute', in the hope that a similar silencing of the incipient feminist voices of the 1970s would not reoccur. ${ }^{20}$

The feminist realignment of understandings of sexual abuse vigorously asserted the essential innocence of the child 'victim' and recast the offender as a transgressive character, threatening the entire notion of childhood. The transgressor, however, was no longer exclusively, or indeed predominantly, the evil stranger. The most dangerous place for the girl child, feminists argued, was, as it had always been, within the family home, made dangerous by the patriarchal power which it embodied. 'Child sexual abuse' needed 'a political interpretation ... situating the problem in the context of male supremacy in and outside the family'. ${ }^{21}$ Introducing the notion of power and powerlessness into the analysis, this reinterpretation reshaped contemporary understandings. ${ }^{22}$

In the 1970s, consciousness-raising groups had broken the silence around rape and incest providing a focus for early feminist research. ${ }^{23}$ The first victim accounts of sexual molestation as a child came from women who were part of the feminist movement at this

\footnotetext{
${ }^{20}$ Above note 18 at 56.

${ }^{21}$ Gordon above note 18 at 63

${ }^{22}$ Angelides Steven 'Feminism, Child Sexual Abuse, and the Erasure of Child Sexuality' (2004) 10 GLQ: A Journal of Lesbian and Gay Studies p 148 at 141

23 McIntosh Mary 'Family Secrets as Public Drama' (1988) 28 Feminist Review: Special Issue Family Secrets: Child Sexual Abuse p 14 at 6
} 
time and they empowered other victims, including men to come forward ${ }^{24}$ Increasing media focus on allegations of sexual abuse in a range of community settings provided the space for the feminist analysis to enter into wider discourse. The dissemination and acceptance of this research saw child sexual abuse removed from the realm of individual pathology and acknowledged as a social and political issue demanding action from governments and the courts. Successful prosecutions recognised the credibility of the child witness creating the opportunity for victims of institutional abuse to bring their testimonies of collective victimisation into the public domain. Although in the general community girls were and are far more likely than boys to be victims of sexual abuse, in the context of the inquiries the original narrative of girls abused by their fathers has been replaced by one dominated by boys abused by priests and other religious figures in institutional settings. ${ }^{25}$

The essentialism which arose from the feminist articulation of child sexual abuse has caused concern to scholars who argue that it has led inevitably to a further disempowerment in its failure to recognise children as sexual subjects. Sexuality scholar Steven Angelides identifies, ' a significant reversal of the common twentieth-century tendency of victim blaming, [through which] the innocent, powerless, blameless, and unconsenting "victim" and

${ }^{24}$ The first such disclosure was made in New York in 1971 by Older Women's Liberation Group member, Florence Rush. For a discussion of this disclosure and its relationship to early feminism see Davis Joseph Accounts of Innocence: Sexual Abuse, Trauma and the Self University of Chicago Press Chicago 2005 p 29

${ }^{25}$ Parliament of Victoria above note 7 at 128; Daly, Kathleen 'Conceptualising Responses to Institutional Abuse of Children' (2014) 26 Current Issues in Criminal Justice pp 9-10 at 5. There have been few attempts to explain the gender disparity that is noted by most inquiries however Parliament of Victoria at 137suggests that higher levels of recidivism amongst perpetrators who target boys may lead to more victims in institutional settings. 
"survivor" of sexual abuse became key cultural terms'. ${ }^{26}$ 'The discourse of child sexual abuse', he argues 'has expanded at the expense of a discourse of child sexuality.' By focusing on issues of power and powerless, he concludes, feminist scholars have profoundly misunderstood 'the dynamics of human sexual and intersubjective relations' avoiding any analysis of some of the 'thorny issues of child sexuality'. ${ }^{27}$

Angelides does not suggest that this erasure of child sexuality was intentional but rather that in the face of rising concern about paedophilia and child sexual abuse the space within which it could be discussed shrank. ${ }^{28}$ Australian feminist scholar, Barbara Baird, shares Angelides' concern, suggesting that child sexual abuse has gained such currency because it resonates with larger concerns about the viability of the nation. In the wake of the evidence of widespread sexual abuse brought to light in the series of child welfare inquiries, she argues, any instance of the sexualisation of children had to be condemned if the national virtue was to be restored. ${ }^{29}$ However, in the process, the prominence given to the 'passive', 'innocent', victim child denied any space in public debate for 'the voice of children whose sexual experience may be more complicated than only victimisation'. ${ }^{30}$ In reality, criminologist, C.W. Gooren argues, 'the innocence/danger dichotomy is undermined by

\footnotetext{
${ }^{26}$ Angelides above note 22 at $142-3$

${ }^{27}$ As above at 150,153

${ }^{28}$ Angelides Steven 'What's Behind Child Sex Panics?' (2011) 2 Lambda Nordica at 101 http://www.lambdanordica.se/wp-content/uploads/2011-23-Angelides-Panics.pdf accessed 20
} March 2015

${ }^{29}$ Baird Barbara 'National Virtue and the "Media Sexualisation of Children" Discourse in Australia' (2013) 16 Sexualities pp 658-9 at 651

${ }^{30}$ Baird Barbara The Resignation of the Governor-General: Family Drama and National Reproduction' (2009) 15 Cultural Studies Review p 70-1 at 65. 
youngsters themselves ... hinting at the generality of paedophilic desire', and blurring attempts to draw a stark line between childhood and adulthood. ${ }^{31}$ Yet to acknowledge such sexual agency is to undermine the many purposes, personal and national, which the assertion of childhood innocence serves.

\section{Care leaver views}

Such views are anathema to both campaigners against, and victim/survivors of child sexual abuse for whom the notion of childhood innocence is critical to establishing their case. However, amongst care leavers and their supporters, there is a concern that with an exclusive focus on sexual abuse as the crime against childhood, other aspects of abuse disclosed by the inquiries are ignored. As Miss T. told the Forgotten Australians Inquiry: 'One of the problems state wards have is that society can relate to and understand sexual abuse. However there does not appear to be an appreciation of the effects of being ... in care'. ${ }^{32}$ Allegations of widespread child sexual abuse in religious and other community settings created a sense of threat that was missing from the broader instances of neglect. The focus on sexual abuse also allowed abuse to be individualised, depicted as the action of psychologically abnormal individuals, and hence diverted attention from the degree to which abuse of all kinds was

\footnotetext{
${ }^{31}$ Gooren JCW 'Deciphering the Ambiguous Menace of Sexuality for the Innocence of Childhood' (2011) 19 Critical Criminology p 30-1 at 29

${ }^{32}$ Submission 214 Forgotten Australians Submissions 2004-7. http://www.aph.gov.au/Parliamentary_Business/Committees/Senate/Community_Affairs/Co mpleted_inquiries/2004-07/inst_care/submissions/sublist Accessed 7 January 2014. Those making submissions to the inquiry had the choice as to whether to use their own names, pseudonyms, or remain anonymous. The submissions cited here reproduce the names attached to the originals.
} 
endemic within institutions which had been trusted to care, and hence from the extent to which society was complicit in what has now been shown to have occurred. ${ }^{33}$ 'Sexual abuse is always highlighted as if it was the "worst" abuse', writes CLAN co-founder, Joanna Penglase. 'What gets lost here is that children were violated in every sense in an institution, and being used sexually was just one of those violations.' ${ }^{34}$ This argument for systemic abuse, in a system in which so many of the institutions functioned under religious auspice, has proven far harder to advance.

\section{Sites of vulnerability}

Evidence presented to the various inquiries supports the claim for sexual abuse as a systemic rather than an individual problem. Rather than being built around idealised notions of childhood innocence, institutions for children were saturated with a sexuality, the presence of which was suppressed, or more often, completely denied, confronting the residents with experiences which they had no language to describe, and against which they had little ability to protest. Boys commonly swam naked, and bath-times for both boys and girls were confusingly sexualised. As a small child at the Salvation Army home in Box Hill, Steve 'wondered at why the person washing me took a lot of time washing my "private parts" ... [with the result that] at times the routine of washing became very painful due to excessive rough handling'. ${ }^{35}$ Relief only came when he was 'old enough to shower, and those episodes were placed and blocked in the back of my mind'. The showers at Mater Dei, Camden,

\footnotetext{
${ }^{33}$ Hawkins Russell, and Freda Briggs 'The Institutionalised Abuse of Children in Australia: Past and Present' (1997) 133 Early Child Development and Care 133 p 42 at 41 ${ }^{34}$ Penglase Joanna Orphans of the Living: Growing Up in 'Care' in Twentieth-Century Australia Fremantle Curtin University Books 2005 p 145

${ }^{35}$ As above note 32 Submission 510
} 
Dianne Witchard recalls, had 'no doors and the nun would stand and watch us but teach us it was a mortal sin to look at each other with nothing on'. ${ }^{36}$ For the boys at St John's Goulburn a similar situation prevailed. 'To look at yours or another body was a sin, and you only touched it if you went to the toilet. Anything else was filth, and a sin. [Yet] the nuns had no problem touching us to hit us, or to look at us in the showers, naked ... One nun came up to me when I was about fifteen and told me I was developing very nicely. This was very embarrassing to a young boy that had been told that desiring the body was an offence' .37 The public display of young naked bodies, John Sanderson has come to understand, served as a 'smorgasbord' from which staff with paedophilic tendencies could select their next victims. ${ }^{38}$

Housed, and often also schooled, within closed institutions, children had a very limited understanding of prevailing sexual norms. There was much in the daily institutional routine that verged on the sexual. John Bryant's experience at Melbourne's Methodist boys' home, Tally Ho, captures this confusion well. Taken to the superintendent's office:

For corrective punishment - for what I know not. He took me on his knee and spoke gently as a daddy. Then came the punishment - ten strokes of the cane being prescribed ... As a prelude to the punishment the Captain would observe: 'My dear boy, this hurts me as much as it hurts you.' I found this hard to believe. ${ }^{39}$

The progression from the 'normal' to the criminal was subtle, leaving the isolated and uninformed child unable to resist. Having been brought up by nuns at Nazareth House,

\footnotetext{
${ }^{36}$ As above Submission 193

${ }^{37}$ As above Submission 330

${ }^{38}$ As above Submission 312

${ }^{39}$ Bryant John There was a Man whose Name was John: An Autobiography. Perth: Selfpublished 1982 p 5
} 
Sebastopol in the 1940s, Alan Coleman was shocked when he was introduced to masturbation by the older boys, but was reassured when he was told that that 'sort of conduct was practised by most of the managers'. ${ }^{40}$ Fondled by a Salvation Army officer on a rare outing to a drivein theatre in the 1960s, James Norman was dissuaded from resisting by another resident, who told him 'it's all right, we all do it ... [he] won't hurt you', but fumbling in the car transformed into a full scale assault in his bed later that night, an incident he is still unable to relate. ${ }^{41}$ Anally penetrated regularly from the age of ten, in his dormitory at the Salvation Army home in Box Hill, Brian Cherrie had nothing against which to judge the situation, describing himself as being 'too young at the time to realise what was even happening'. ${ }^{42}$

Abusers played on the children's vulnerabilities. Barry Maslen self-identified as a sexually available 'bumboy'. Living at a Salvation Army home in the 1950s and 60s he was lured into one of the officer's room by the offer of treats. 'We never got Milo, biscuits or lollies at Riverview, so he knew how to lure me ... Each time I was tempted by the treats and hoped that the sexual abuse would not follow. ${ }^{43}$ Comforted by one of the Christian Brothers after a severe beating at St Augustine's, Geelong, in late 1950s, Bryan Glanville thought he 'had a friend, and as I had never been shown affection by another human being that I could remember, I welcomed it'. With the help of lollies, cigarettes and wine the relationship developed until Glanville was regularly abused in the brother's room. Although his initial

\footnotetext{
${ }^{40}$ As above note 32 Submission 471
}

${ }^{41}$ As above Submission 399

${ }^{42}$ Parliament of Victoria Family and Community Development Committee Inquiry into the Handling of Child Abuse by Religious and Other Non-Government Organisations Submissions 2013 http://www.parliament.vic.gov.au/fcdc/article/1789 accessed 29 March 2014

${ }^{43}$ As above note 32 Submission 75 
reaction was to resist, eventually he 'got to the stage where I thought stuff it, I get a smoke and a drink of plonk, all I've got to do is whack him off'. ${ }^{44}$ Only when he discovered that other boys were providing similar services but being paid more did he join with them to attempt to expose the offender. Obliging the abuser also brought an element of protection. At St Augustine's, Leslie Burr recalled, 'the Brothers ... had favorite boys ... the sissy types [who] never got bashed like the rest of us'. ${ }^{45}$

Yet acquiescing was rarely a choice. What is striking from survivor accounts is the almost complete inability of institutionalised children to control access to their own bodies. When one of the officers at the Bexley Salvation Army Home took a group of boys on an outing in the 1930s, Jack Healy found his pleasure quickly staunched. 'On the train he would spread his coat over his and our laps and start to touch us to arouse us. On arrival he would tell us to go for a nude swim, [but] he usually left one back, when he would begin his sexual abuse. He was insatiable. ${ }^{46}$ At St Vincent's South Melbourne, Mark McCabe was assaulted by a brother to whom he had gone for medical treatment. ${ }^{47}$ More commonly the intrusion came in the dormitory at night. At the Salvation Army home in Goulburn in the 1940s Ralph Doughty recalls officers touching boys in the genital area and watching to see what would happen, hitting the penis if it became erect. ${ }^{48}$ Sent to St Augustine's in the 1950s, William Davis came to realise that the dormitory was set up in a way which facilitated abuse. 'It was always the same. I would get out of bed to turn off the light, he would shut the door and start to fondle me ... as he was fondling me he was moving towards his room. Once I was in the

\footnotetext{
${ }^{44}$ As above Submission 129.

${ }^{45}$ As above note 42

${ }^{46}$ As above note 32 Submission 411

${ }^{47}$ As above Submission 38

${ }^{48}$ As above Submission 282
} 
room he would shut the door. ${ }^{49}$ Regularly summoned from his bed at the Salvation Army Boys Home at Nedlands in the 1940s Ernie Tulloh was powerless. 'Waiting at night in bed was awful - I was so frightened that he would come and get me, and he did. Even if I faked being asleep he would shake me and I knew I had to get up or I'd get flogged.' Initially too frightened to complain, later he was too ashamed so the 'abuse went on until they shoved me out of the home at 15 years old'. ${ }^{50}$

It was not only within the institutions that children were at risk. The practice of holiday hosting provided another source of danger. Mark McCabe, who was living at Vincent's, South Melbourne in the 1950s, came to believe that an annual picnic organised for the boys served as a 'meat-market' with 'some people ... selecting the boys they wished to billet out at Christmas ...[alleging] there was plenty of anecdotal evidence that boys were sexually assaulted during the Christmas holiday period'. ${ }^{51}$ Abused by his holiday host in a caravan park shower block, Peter Smith felt completely powerless. 'I had no knowledge of phone numbers of either my parents or house parents. Also, by this stage I had already learnt not to trust anyone and was wary of informing people of my abuse, as I was afraid it would only make things worse. ${ }^{152}$

Assaults both within and beyond the institutions were made even more confusing because they were committed in environments and by people who were overtly religious. Patrick Parkinson has observed that 'the power and influence that clergy have can be used for great good or can be gravely misused. Since in religious communities, priests or ministers are influential in defining the boundaries of what is right and wrong, they have the power to

\footnotetext{
${ }^{49}$ As above Submission 227

${ }^{50}$ As above Submission 496

${ }^{51}$ As above Submission 38

${ }^{52}$ As above Submission 527
} 
define abusive behaviour as normal'. ${ }^{53}$ Arguing that abuse has always been present in religious organisations, Fiona Hill points to ways in which 'the appearance of innocence' could be maintained by 'power games, including appeals to the Bible, and a range of strategies that ensured victims were silenced and marginalised'. ${ }^{54}$ Children struggled to make sense of abuse which took place in sacralised spaces, the sacristy of the orphanage chapel for Margaret Finn ${ }^{55}$ in the 1950s, or, for Wayne Laird, in the 'red glow' emitted by the statue of St Vincent de Paul. ${ }^{56}$ Abused children struggled to reconcile actions and words. 'In church every Sunday', one Kilmany Park resident recalled, 'we were told of this God of love and understanding who was watching over us. I could not understand, because I thought: "Jeez, what's happening? He's not watching over me". ${ }^{57}$ Every night, the brother who was regularly abusing Vincent Dromi at St Vincents, South Melbourne in the 1970s would ' say things in my ear like "god bless you", when he kissed me goodnight'. 'Why did he say that to me?' he now wonders. Was it an admission that he had 'hurt me or was he saying it was ok to do that to us $?^{158}$ In a confused account an anonymous respondent who had been in care in a series of institutions in the 1960s and claimed to have been abused by priests in each location, abuse

${ }^{53}$ Parkinson Patrick 'What Does the Lord Require of Us? Child Sexual Abuse in the Churches' (2002) 4 Journal of Religion and Abuse p 13

${ }^{54}$ Hill Fiona 'Churches as Partners in Institutionalised Abuse: Disarming the "Bible-bashers"' (2005-6) 18 Women Against Violence p 5 at 5

${ }^{55}$ Parliament of Victoria Family and Community Development Committee Inquiry into the Handling of Child Abuse by Religious and Other Non-Government Organisations Transcript, 2012-3 p 4 http://www.parliament.vic.gov.au/fcdc/article/1786 accessed 30 March 2014

${ }^{56}$ As above at note 32 Submission 15

${ }^{57}$ As above at note 5 Australian Senate 200446

${ }^{58}$ As above at note 32 Submission 371 
and religion were intertwined with the assault being accompanied by a recitation of the Our Father and the Hail Mary, as if to confer forgiveness in the very midst of the sinful act. ${ }^{59}$

\section{Silencing mechanisms}

This quasi-religious sanction also made it difficult for children to report abuse. The state entrusted children to the care of these organisations because they were religious and hence assumed to be above reproach. ${ }^{60}$ The level of trust was such that inspection was minimal leaving children with virtually no-one outside the institution to whom they could speak. ${ }^{61}$ Even in cases where children or their families attempted to speak out, they were unlikely to be believed. McAlinden has labelled this phenomenon 'social denial' grounded in a 'culture of disbelief' around clerical abuse. ${ }^{62}$ Silence also prevailed within religious organisations where a belief in the sanctity of suffering, and the power of forgiveness acted against the recognition of such behaviour as a criminal offence and deciding to act accordingly. Through this process the abuser became the victim, and the survivor was rendered un-Christian for demanding justice rather than offering forgiveness. ${ }^{63}$

Steve understood this dynamic and never thought to disclose the Salvation Army officer's behaviour 'I was so scared at what would happen to me if I told anyone, no-one would believe me as I was only a child and they were trusted officers'. ${ }^{64}$ The boys assaulted from around the age of ten by the dairyman at St John's Goulburn, felt powerless, for to alert

\footnotetext{
${ }^{59}$ As above Submission 419.

${ }^{60}$ As above at note $6 \mathrm{p}$ vii

${ }^{61}$ As above p 102.

${ }^{62}$ As above at note 8 p 22-3

${ }^{63}$ As above at note 54 p 6

${ }^{64}$ As above at note 32 Submission 510
} 
the nuns was to confess to 'committing sexual acts and then being bashed for it'. ${ }^{65}$ Others were more trusting. Margaret Finn reported her assault to the Sister in charge, only to be called 'a liar and a wicked, wicked child' and threatened with severe punishment if she raised the matter again. ${ }^{66}$

Ralph Doughty is adamant that such reactions arose out of denial rather than disbelief. The officers at his Salvation Army home, he argues, 'would have witnessed the exploitation, the bashings, the caning, the deprivation of sleep, the exhaustion from overwork, the withholding of food, the silence torture, the standing at attention in line torture, the sexual abuse, the sexual embarrassment and the many other ways that a child can be abused', yet noone intervened ${ }^{67}$ Bryan Glanville recalls that when the boys at St Augustine's attempted to expose an offending brother, the reaction was swift. Addressed by the superintendent they were told "'There is a rumour going round ...[and] if I hear one more word of it you will be up before the court on a charge of defamation of character, and you will be sent to Royal Park". His parting shot, "Who would believe you toe rags".' ${ }^{68}$ Complaining to the police after being assaulted at St Vincent's South Melbourne, Mark McCabe's experience confirmed the superintendent's judgment. When he finally absconded and went to the police, he was 'thrown in the wet-cell' with the drunks, punched by a detective and told 'not to bother coming to the Police Station with such cock and bull stories' and then returned to the custody of his abuser. ${ }^{69}$

\footnotetext{
${ }^{65}$ As above Submission 330.

${ }^{66}$ As above at note 55

${ }^{67}$ As above at note 32 Submission 282

${ }^{68}$ As above Submission 129

${ }^{69}$ As above Submission 38
} 
Even where children were able to have their accusations heard outside the institution, the officials to whom they spoke colluded in dealing with the complaint internally rather than risk damage to the reputation of the church and indirectly of those who had entrusted children to its care. When Wayne Laird finally absconded, his injuries were sufficient to persuade the police of the truth of his story. The detective took him back to St Augustine's and demanded to see the offender. As the brother 'came through the swinging doors, he was met with the sergeants big fist. This laid [him] on the floor ... The burly copper stood over him and warned of further repercussions if he ever saw another boy in the condition I was in'. While Wayne was 'free of this creep sexually' he still had to live with what he described as 'his perverted revenge' and no charges were laid. ${ }^{70}$

Laird's experience is indicative of the degree to which external authorities were complicit in preserving the reputation of religious institutions. The pattern that emerges from the evidence given to the various inquiries is confirmed in institutional files. In some cases where children reported abuse, they noticed that action was taken. An offending staff member left suddenly or was relocated to another area of the home where they were less likely to do damage. ${ }^{71}$ Sometimes a note was placed on file barring the accused from further interaction with children, but no-one gave an account of institutional authorities ever contacting the police. ${ }^{72}$ Departmental files confirm that in cases where complaints had been made to external authorities, their first recourse was to go back to the institution to seek a resolution. If the offender was a staff member, the Superintendent or matron was usually able to resolve the matter by a quiet dismissal. In cases where the superintendent himself was at fault, board members or church authorities stepped in to ensure that he was quickly removed. In the few

\footnotetext{
${ }^{70}$ As above Submission 15

${ }^{71}$ As above Submission 473

${ }^{72}$ As above Submission 374
} 
instances where the state department referred the matter to police, the cases seldom progressed because police doubted that the evidence of the victims would be believed in a court. Without witnesses, it was assumed, the word of a child would not stand up against the word of a respected adult for whom the loss of the position was considered to be sufficient punishment. $^{73}$

\section{Institutionalised children as 'moral dirt'}

In all of these discussions, the eye of pity fell upon the abuser, perhaps a once trusted former colleague now faced with disgrace, and the impetus was to minimise that harm. The focus was on providing opportunities for the sinner to repent rather than pursuing justice for the child. But, as Parkinson has persuasively argued, forgiveness in such cases became 'a spiritual argument for avoiding the consequences of the crime, and negating the need to deal with his offending behaviour'. ${ }^{74}$ In order to understand the indifference to the child it is helpful to invoke Harry Ferguson's argument about institutionalised children as 'moral dirt'. The harsh treatment which such children received, he writes, was not aberrant but essential to the purpose of child rescue. Removed children 'were treated harshly because they were victims of cruelty...the key to unravelling the meaning of child abuse and institutional care lies in understanding the concept of neglect and its links with sexual morality and the notion of "moral danger". 75

${ }^{73}$ Information comes from institutional files held in the Victorian Department of Human Services archives. Access covered by confidentiality agreement.

\footnotetext{
${ }^{74}$ As above at note $53 \mathrm{pp} 14-15$

${ }^{75}$ Ferguson Harry 'Abused and Looked After Children as "Moral Dirt": Child Abuse and
} Institutional Care in Historical Perspective' 200736 Journal of Social Policy p 131-2 at 123 
At the Melbourne Orphanage in the 1940s and 50s, any overtly sexual behaviour was read as evidence of 'moral degeneracy'. This judgment was clearly internalised by Doug McNeil who, when he could not rid himself 'of the pleasurable thoughts associated with' the sexual abuse he received in the Melbourne Orphanage, became convinced that he was indeed a 'filthy guttersnipe ... loathsome swine ... and vermin' and deserving of the punishment administered to him. $^{76}$

\section{Coming out as victims}

The feminist reconfiguration of child sexual abuse gave care leavers the language and the tools to challenge this self understanding. The identification of abuse as an exploitation of adult power which represents a major breach of trust provided the means through which victim/survivors, in their emerging support groups, could come to a new understanding of their experiences. These support groups brought care leavers into an alliance with the much wider groups of adults abused as children in other church and community sectors adding to the valency of sexual abuse as the greatest transgression of childhood innocence. Whatever the circumstances in which the sexual interaction occurred, they were children, and hence, by definition, were unable to give informed consent. By 'coming out' as victims care leavers were able to access the self-help groups which played such an important role in the social activism of the 1970s and beyond, or to create self-help groups of their own around a similar model. ${ }^{77}$ Blending emotion and policy these groups functioned to change both the inner world of the individual and forced the larger social world to confront their issues. ${ }^{78}$

\footnotetext{
${ }^{76}$ McNeil Doug Order of Things Bentleigh Doug McNeil. 1995 p 17-18

${ }^{77}$ Whittier Nancy The Politics of Child Sexual Abuse: Emotions, Social Movements and the State Oxford: Oxford University Press 2009 p 68

${ }^{78}$ As above pp 208-14
} 
While the testimony given before the various inquiries encodes much of the childish helplessness with which care leavers encountered the original abuse, it also provides evidence of the ability to reframe such experiences in line with this new vocabulary. The evidence is shaped by what Ahmed and Casey have labelled 'testimonial culture' which allows for a reworking of 'autobiography, confession and remembrance' ${ }^{79}$ Testimonies, Rosanne Kennedy reminds us, are never simple representations of the past, but rather function as 'social utterances which intervene in a present social context', addressing what Bain Attwood has called 'the past's residue in the present rather than ... the pastness of the past' ${ }^{80}$ Central to that residue is the dysfunction in individual lives for which the public naming of sexual abuse can now give an explanation.

The glimpses of this new understanding are evident in the testimonies in several ways. Often it surfaces in angry outbursts which employ post-1970s terminology to condemn past abuse. Having described how the Colebrook Home in South Australia became 'a haven for sexual deviants' after its founders retired, Ruby Hegarty slips into a human rights discourse, arguing that 'as children we were robbed of our personal rights'. ${ }^{81}$ The publicity surrounding the exposure of offenders within the Catholic Church, allows children who grew up in its

\footnotetext{
${ }^{79}$ Ahmed Sara and Stacey Jackie 'Testimonial Cultures: An Introduction' 20015 Cultural values $5 \mathrm{p} 1$ at 1

${ }^{80}$ Kennedy Rosanne. 'The Affective Work of Stolen Generations Testimony: From the Archives to the Classroom' 200427 Biography p 49 at 48; Attwood Bain 'Settling Histories, Unsettling Pasts: Reconciliation and Historical Justice in a Settler Society' in Manfred Berg and Bernd Schaefer (eds) Historical Justice in International Perspective: How Societies are Trying to Right the Wrongs of the Past edited by. Cambridge: Cambridge University Press 2009 p 236 at 217
}

${ }^{81}$ Kartinyeri Doris. Kick the Tin North Melbourne Spinifex Press 2000 p 54) 
institutions to link individual prosecutions to their experiences. Rosemary Beggs, for example, cites the findings of the Forde report to validate her claim that the Church chose to hide paedophile priests in its children's homes. 'We accepted it was their right', she argues, 'for we knew nothing else. Nobody from the State Children's Department cared what was happening to us'. ${ }^{82}$

The new understandings are also evident when care leavers use their submissions to reflect on the damage that they have come to believe their abuse has caused. Now describing himself as 'homosexual (from birth I assume)', John Lloyd admits to eventually welcoming sexual advances, but believes that the shame that accompanied such behaviour led him into increasingly anti-social activity and violent crime. ${ }^{83}$ For Ann Thompson, the new vocabulary provides little consolation. Identifying as one of those 'who were unlucky enough to be singled out as "the chosen ones" of the priests, nuns, lay workers and the older girls ... who picked us out to sexually abuse' she believes that she is 'scarred ... for life ... [adding] no amount of counselling can cure ... the pain I feel within'. ${ }^{84}$

For all of its despair, Thompson's use of the term 'chosen one' is indicative of a buying into a new and shared identity created initially by the post-1970s understandings of sexual abuse, and consolidated through the investigations of institutional abuse in the years since. For one former resident of the Melbourne Orphanage the possibility of this new identity creates confusion.

Everybody always asks me if there was any sexual abuse while I was at these places 'as a ward of the state'...nowadays everybody knows this 'sex abuse' as a crime against society. When you're a child in the fifties and sixties you don't know much about this

\footnotetext{
${ }^{82}$ As above at note 32 Submission 202

${ }^{83}$ As above Submission 210

${ }^{84}$ As above Submission 410
} 
type of stuff ... I have memories and can tell certain things if I feel that I should, but I wonder what really happened and how much is fabricated as in a dream or in the mind because society says it must have happened. I really don't think I'm that sure of details and specifics of another life and time or at least not sure enough to state a fact without fear of error. ${ }^{85}$

Others have no such doubts. Child migrant, James Albert McGregor, describes the environment of the Christian Brothers homes to which he was transported quite simply as 'the kingdom and reign of a paedophile'. ${ }^{86}$ William Allen validates his testimony simply by positioning himself of an inmate of 'the notorious Neerkol orphanage'. ${ }^{87}$

\section{Conclusion}

The reassertion of childhood innocence that was central to the 1970s feminist (re)discovery of child sexual abuse has provided care leavers with a valuable discursive tool in their struggle for redress. While its closure of a space in which to discuss childhood sexuality is proving problematic, that is an issue for the present which has little relevance for people dealing with residues of the past. Long after the redefinition of sexual abuse as an issue of patriarchal power has slipped from the centre of feminist debates, care leavers and other child abuse victims have been able to use such arguments to shame religious authorities, displacing them from their central position as guardians of national morality. This displacement was vividly demonstrated at the 2013 Victorian inquiry when the Catholic Archbishop of Melbourne, Denis Hart, replied to accusations that the church had not responded to abuse victims by remarking 'People will make their own minds'. Committee

\footnotetext{
${ }^{85}$ As above Submission 465

${ }^{86}$ As above Submission 34

${ }^{87}$ As above Submission 219
} 
member Andrea Coote replied: 'The victims have made up their minds. They do not believe what you are saying'. ${ }^{88}$ The shift from people to victims is crucial, for while the church continued to appeal to an understanding still widely believed within the male clerical hierarchy and their almost exclusively male advisors, its representatives misunderstood the degree to which the victim voice has now become the dominant discourse shaping contemporary understandings of clerical abuse.

This article has argued for the importance of feminist discourses around child sexual abuse in enabling victims of institutional abuse to find a language in which to reconceptualise their experiences in out of home care. In so doing it has allowed them to discredit the attitudes that prevailed during their childhood that looked-after children were morally inferior, and that the predominantly religious organisations that had responsibility for their care were above reproach, an attitude which simultaneously exposed such children to higher risks because of the lack of official oversight and discredited any attempts they made to bring attention to their abuse. While the language of victimhood may come at a price it has given care leavers in Australia and beyond a powerful position from which to capture the attention of governments, to narrate their experiences of abuse and assert claims for redress.

${ }^{88}$ As above at note 55 20-May-13 